\title{
The Discussion on Feminization of Migration
}

\author{
Kadınların Göçü Üzerine Bir Tartışma
}

http://dx.doi.org/10.22559/folklor.1702

\author{
Dilan Çiftçi* \\ Oben Kaya
}

\begin{abstract}
Immigration and asylum matters in particular that affect society in various ways began to attract attention after the period of Second World War. There has been a mass escape from oppressive and fascist regimes in the Second World War period. However, period of the Second World War was special because of causing the massive displacement and migration. During this period, the dominant view about the issues of migration and asylum problems was in the direction of "asylums were victims of war and in need of protection." As a result of many events and wars occurred in recent years, many refugees who escape from ethnic or religious conflict are waiting for asylum or placed to some places as refugees. Again seen in the last period, many people escaping from the conflict in Kosovo, Afghanistan, Palestine, Africa and in addition Syria are displaced as refugees throughout the world. This study will focus on analyzing the relationship between women and migration in the size of refugee women rather than the general conditions of refugees and migration. Having preferred to examine the dynamics of relations between women and migration is derived from the development of migration history and migration process.
\end{abstract}

Keywords: migration, international migration, human rights, women, women wights, weminization of migration.

\section{Öz}

Toplumları çeşitli yönlerden etkileyen göç ve özelde sığınma konusu ikinci Dünya Savaşı sonrası dönemde dikkat çekmeye başlamıştır. İki dünya savaşı arası dönemde baskıcı ve faşist rejimlerden kitlesel kaçışlar yaşanmıştır. Ancak İkinci Dünya Savaşı kitlesel yerinden edilmeler ve göçler yaşanmasına neden olduğu için özel bir dönemdir. Bu dönemde göç ve sığınma problemi ve dolayısıyla sığınma konusundaki hakim görüş "sığınanların savaş kurbanı ve korunması gereken kişiler" olduğu yönündedir. Son dönemde yaşanan pek çok olay ve savaşın sonucunda olduğu gibi etnik ya da din tandanslı çatışmalardan kaçan pek çok mülteci, sı̆̆ınma beklemekte ya da sığınmacı olarak bazı bölgelere yerleştirilmektedirler. Yine son

* Doç.Dr. Uluslararası Kıbrıs Üniversitesi İletişim Fakültesi. dciftci@ciu.edu.tr, ORCID: 0000-0003-3806-3915 
dönemlerde görülen Kosova, Afganistan, Filistin ve bazı Afrika örneklerine ek olarak Suriye'deki çatışmalardan kaçan pek çok insan da sığınmacı olarak dünya üzerinde yer değiştirmektedir. Bu çalışma; sığınmacıların genel durumları ve göç kavramından ziyade, kadın ve göç ilişkisini sığınan ve sığınmacı kadınlar boyutunda incelemeye odaklanmıştır. Kadın ve göç ilişkisinin dinamiklerinin incelenmesinin tercih edilmiş olmasının göç tarihi ve göç süreçlerinin gelişiminden kaynaklanan bir temeli bulunmaktadır.

Anahtar sözcükler: göç, uluslararası göç, insan hakları, kadın, kadın hakları, kadın ve dişiselleş̧tirilmiş göç.

\section{Introduction}

\subsection{The Concept of Migration}

Several definitions are made on immigration and each definition emphasizes different aspects of migration. According to a definition, migration is defined as people's transition from a residential area to another area within a certain time. (İçduygu and Ünalan, 1998: 38). Another definition has made by Tomanbay (1999: 103) and according to this definition; migration is defined as the displacement of a person, family, group and community for the purpose of settlement and living in another community by living the society in which they live continuously because of a variety of reasons as economic, political and cultural and so on. Bhugra (2004: 243) defines migration as a process in which people participate for the purposes of working, better jobs, better future, marriage and escape political/religious persecution.

If we want to define the movement because of different reasons as migration, the person must leave his or her home community for the aim of living and settling another place. So, forefront of the intention of being permanent is said in defining the concept of migration. Regardless of the cause, experiences before and after the migration carries different characteristics in terms of each individual and the situation may show even bigger differences for women. Women joined the first migration by initially following the male family members, over time, they became independently and on their own immigrants. This situation requires us to understand the dynamics of women migration.

\subsection{Migration of Women}

Women's immigration should be understood as the immigration in which all women are active in the process and involving alone since the issue of the migration decision. Although men and women migrate at the same rate, when the studies and research examine, it is observed that women's size in migration is ignored. The reasons for this situation has been demonstrated by International Research and Training Institute for the Advancement of Women (INSTRAW) (1994: 3-4) as follow; 
- literature of migration mainly focus on economic migration,

- the economic activity of women and their participation in the labor force should not be given a value,

- women in academic social science research generally invisible,

- most of the research on migration made by men

- depending all them, there is lack of information on women's migration.

Reaching the same ratio of men and women both in optional and forced migration requires special consideration of women's migration. While men tend to migrate only for work in the past and women remain in the country for the care of children and their family, today women are independent and immigrants themselves. Although this independent immigration is seen as a development, structural factors as poverty and inequality of opportunities are seen effective in migration decision of women. While women constitute $48 \%$ of the 150 million migrants worldwide, this ratio is even higher in some regions. The lowest rate of immigrant women is in Middle Eastern countries, $60 \%$ of migrants are women in Sri Lanka. (INSTRAVV, 1994: 67). Realization of women's migration approximately at the same rate with men requires us to address the causes of women migration.

\subsection{The Causes of Women's Migration}

When examining the causes of women's migration it is often seen that the first explanation based on economic reasons. Women migrate because of various reasons which they may have little control over like poverty, debt and other external constraints. Wage differentiation in the destination country affects the decision to migrate, but this is not the only reason. Some non-economic factors such as the marital discord, physical violence, disrupted and unhappy marriages and difficulty of divorce are particularly important for women migration. (Kofman, Phizacklea, Raghuram and Sales, 2000: 143).

Violence against women is mentioned as a major reason for migration decisions. The use of sexual violence against women in war and conflict situations has become widespread. Women encounter with all forms of sexual violence during war and armed conflict and it is emerging as a situation almost inured and encountered worldwide. In addition to the sexual violence, women all over the world took a global view with various types of persecution, human rights violations and other gender-specific restrictive traditions. In addition, the status of women face a number of restrictions and discrimination resulting from gender also has a global view.

Women face with gender-based discrimination in employment, unequal wages, inadequate health care and public health services, inadequate training, limited resources, child care and household responsibilities. (Anker, 2002: 6). These reasons are the basis of all 
factors of migration for women. Especially understood from the description in connection with employment is that broader structural factors affect women's opportunities. According to Kofman, Phizacklea, Raghuram Satış, 2000 Tarih: 143; Crawley, 2000: 18; Halfacree, , not to see the structural factors that influence migration continues to embrace women as passive and powerless victims and tendency not to see the oppressive social structures. In fact, it is necessary to take a structural variable such as patriarchy into account in the migration process. The situation of not to fulfill a number of roles expected due to gender can lead to migration of women. Thus, it should be considered that the patriarchal structure could lead to women migration all over the world.

Due to age or position in the family, the desire to avoid discrimination that women especially complain is also effective in migration. The link between "perceived opportunities" and "real opportunities" for women affects migration. Women can see the migration as escape from the oppressive structures in place they live and resist the opportunity. (Kofman, Phizacklea, Raghuram and Sales, 2000: 143). It is observed that, specific causes of women migration are largely about living in a patriarchal society and the restrictions due to the expected gender roles of women. However, in addition, it is better to take into account the factors linked to the economy. Therefore, being aware that there are many economic and non-economic causes of migration of women is very important. It is seen that, the causes of migration cannot being explained based on a single cause; it became valid when the status coexistence of several of different reasons many times. In the following sections, approaches trying to explain the female migration are concerned about the level of female migration in terms of conceptualization.

\subsection{Migration Theories and International Migration}

When migration theories and explanations are looked in terms of asylum, conceptualized mentions about the subject are limited. Migration theories are in particular linked to employment, especially since the 1970s and tried to explain the actual labor immigration to meet the workforce for reconstruction of the country. Therefore, firstly general theories used to describe international migration are examined. Then, theoretical classification is referred for describing the economic dimension of women's migration.

There are three theories of international migration group; basically macro, mezzo and micro-including. (Boswell, 2002: 6). Macro theories emphasize the objective conditions as structural and "push" - "pull" for the realization of migration. Some of the driving factors in case of economic migration are employment, low wages and per capita income in the destination country. Some of the attractive factors are the immigration laws of the destination country and the labor market situation. The second group mezzo theories refuse to focus on the macro push and pull factors and describe the migration as a complex system that includes the links between states. The two concepts are particularly 
important in mezzo theory; systems and networks. These theories emphasize that migration occurred in economically, culturally and politically interconnected countries system. The third group micro theories focus on individual causes that affect people's decision to migrate. These theories focus on the migratory behavior of individuals instead of identifiers of all migration flows.

The approach to women's migration appears to be quite limited within conceptualizations of migration. Among these, it is possible to speak from two basic classifications. The first classification made by Chant and Radcliffe (1992: 19) and accordingly, four main conceptual approaches on women's migration may be mentioned: balance/neoclassical approach, behavioral approach, structural approach and household strategies approach. Balance/neoclassical approach explain migration as a move of women from rural areas to the urban labor market that has more employment opportunities with an emphasis on spatial distribution of the job market. Behavioral approach is more sensitive about women's migration, ideological and cultural structures that affect the position of women and men and the changing socio-economic situation. Changing economic sectors underline that geographic mobility and participation rates are shaped by cultural and class differences components. Structural approach uses more general and global perspective in explaining the migration of women. Work space redistribution and the relationships with the world economy explain differing mobility by gender. Production relations, transformations in production areas, this transformation's impact on women and the concept of reproduction are important according to this approach. According to household strategy approach, household production is seen as important as wage and job opportunities in explaining migration of different gender in rural households. According to this approach, the gender division of labor within households is as important as meeting the requirements of life. (Chant and Radcliffe, 1992: 20-23).

Various criticisms have been directed to these approaches. Balance approach has been firstly criticized because of not showing the different types of women's migration enough. Educational success and explanations based on rural-urban origin were inadequate. It is claimed that differences as class among women, the current period in the life cycle and cultural back fields are denied. Secondly, not pointing the social factors affecting the conditions of participation of the migration flows and ignoring the labor markets of origin and destination country is reported. Thirdly, this approach has been criticized because of behaving women as a "special" group and seeing their participation to the migration flows as understandable. Behavioral approach has been criticized because of the tendency to generalize the characteristics of male and female migration beyond the specific community or area.

Structural approach has been criticized because of the importance given to the macro concepts such as global perspective and production by neglecting micro factors. Household strategies approach has been criticized because of being tested by research. 
(Chant and Radcliffe, 1992: 23). Generally, theories explaining international migration and the first group approach that examines women's migration basically seem to explain economic migration. Women's migrations are discussed in the framework of business, employment, economy and production concepts. These approaches do not appear to provide an adequate framework about migration of refuge and asylum-seekers women.

Women migration approaches offered for refuge and asylum women underline the detections about women's different experiences, adding women to existing men migration model may be inconvenient and the special status of women which need to be addressed separately. This second group descriptions are Cravvley's (2000: 17-19) descriptions and it is important to reveal the specific side of migration of refuge and asylum women. This approach explains the woman with two sub-migration approach: male versus female models and content versus interpretation.

Crawley (2000:18) implies that "female models" are generally added to "male experience" and this case generalizes women's experiences and "gender-based persecution" and focuses on resistance and regressions that women experience in the country of origin. Crawley (2000: 18) indicates that in the female approach against male approaches, the differences among women have important implications on the experiences of persecution and asylum recognition process. This approach is stating that adding women to the available analysis without a clear understanding strengthens the appearance of women as only victims and also propounds that while asylum-seekers women are presented as poor, weak and vulnerable, Western women are presented as modern, educated and free sexually. This is creating an effect that eliminates the conceptual and political aspects of women's experience of persecution and conceptualized women as passive victims. This approach is examining important points in the analysis of asylum-seekers women migration because of determining that women's political participation is not tolerated by society and cultural and political rules limit the political participation of women.

The content approach to review considers that in the refugee recognition process, women should be conceptualized not as a specific cases deviating from normal but as a group whose experiences are completely understood and thus conceptualized. This approach is looking for the "problem" not as women's invisibility, but how their experience is presented and identified analytically. (Crawley, 2000: 19). Asylum-seeker women have different set of characteristics than women located in the other immigration category. These features are discussed in the next section.

\subsection{Exception of Refuge Women}

Asylum is a condition which causes and results have the complexity and diversity. However, despite their differences, there are common sides as defection experience, forcibly be removed from similar patterns of daily lives experience, multiple losses and 
struggling to maintain their lives (Eastmond, 1993: 36). As is known, right of sanctuary occurs in case of the violation of some rights in the country of nationality. However, as human rights mechanisms created by men, women's rights are not almost mentioned specifically until the 1980s. In the 1980s, it was being discussed that women-specific human rights violations, in other words, asylum reasons specific to women could be found. Proper reviews about the understanding of violations of women rights have been added to the legal systems about existing human rights. (Female Refugee, 1997: 8).

Women, like all asylum seekers, are fleeing because they are in fear of persecution and oppression. But women, unlike men, are obliged to leave their country and refuge in another country in order to escape from such oppression and repression that they face just because of being women as gender-based discrimination, persecution and oppression as of social and cultural prejudices, damaging practices disrupt the physical and mental health, sexual abuse, sexual violence, domestic violence which are not all indicated specially in 1951 Convention. (Akkaya, 2002; 77).

For most people and especially for women, pressures created by the war follow leaving home and being asylum-seekers. Women, with their husbands or without them, have to fight for the survival of their families (Nikolic-Ristanoviç, 2003: 2-4). The majority of refugees in the world come from less developed countries. Refugee women and children naturally have such problems in these less developed countries as poverty, malnutrition, lack of safe drinking water, large family size, high child mortality rates and deficiencies in health care in these countries, which are inherently less developed, the lack of and food shortages, living problems such as care. In addition to the conditions, such special cases as asylum case of persecution, violence and other traumatic events are highlighted by Martin (1992: 4) and Friedman (1992: 65).

In countries which war affects, women enter into extramarital relationships with men who give them food and other supplies. There are no major differences in this respect between the one with little boy, married or unmarried women. (Nikolic-Ristanoviç, 2003: $2-4)$. For women faced with persecution, to access information about the legal process related to asylum is a very important issue. Beyond the legal barriers, there may be barriers related to logistics and information, cultural and psychological. Women are less mobile than men and therefore having access to a place to ask for asylum is more difficult. In addition, women's control over resources is also less. When usually a woman apply with a man to be a refugee, just the claims of men are listened, women are not involved.

Küncek (1998: 4) collects the problems faced by refugee women under three headings as problems at "home", experienced during the escape and in the camp, and in the new house. According to this classification, problems that occur before they come to the position of refugee take place in the first group that women face with. During the escape, because women have to look after children and older people closely in the family, if the escape is to be made on foot, women are generally much more vulnerable to 
attacks on convoys and stay in the back of the opposing group. When a camp is reached, women suffer greatly in the armed attack to the camp. In destination countries, hope of refugees start to a new life in this country.

Refuge and asylum-seekers is seen as a special case of women. Refuge and refugee women migrate because of more different reasons in addition to all women's migration reasons. After emigrating, they face with some additional difficulties. In this study, it was benefitted from the disclosure of feminist theory to reveal and make refuge and asylumseekers women experiences visible. Therefore, in the following section, there is a debate in accordance to the contributions of feminist theory to migration field.

\subsection{Feminism's Contributions to the Field of Asylum}

Feminist theory is a theory that tries to make women problems visible in all areas of life and to understand and try to explain the dynamics of their inferiority. Feminist theory is expected to present a functional such framework from the fact that female experience is not visible during the migration in the context of women and migration relationship as revealing the women's place, conceptualization of migration experiences from women's perspective. Countries where asylum problem occurs are generally referred to as less developed or underdeveloped and the ones where the status of women and their participation to social life are relatively more limited. The systems that base oppressive and religious references in these countries adopt a management style that legitimizes women's inferiority and design social life according to this understanding. Thus, women have the problems arising from this traditional approach. As well as works that make women secondary, also prepare the ground for shelter for women, for example, women participating opposition groups and struggling because of traditional practices in their country are punished twice by the regime because they conduct political struggle. Women are not tolerated both because they refuse to conduct traditional female roles and they claim in a political area considered as men area. The various forms of violence to include domestic violence traditionally for women living in countries seen as legitimate for women, this situation can be seen as persecution example arising from gender; it paves the way for the resort to another country to seek refuge for women.

When the first feminist studies on immigration are examined, it can be seen that since the 1970s, in the context of feminist migration research, some researches focus on the symmetries between men and women migration (such as women's relationship network of male migrants and relatives were in line with the relationship network), the private side of female migration - for example to the liberating side of migration or to sex workers-. First feminist research in the field of migration has followed an approach "that women have contributed to" (Prodolliet, 1999 Akt: Pessina and Mahler, 2003: 13). Primarily, when the migration history was written, the need to record the women's place 
and actions in the migration process was highlighted. These efforts have led to studies on female migration to a more general perspective.

Gender has becoming a category that configures migration process like configuration of migration decision. A notable criticism has come from white and non-Western women who do not accept women's categories as universal. This criticism, by passing a third stage, has led to the recognition of the fact that the women vary and restructure according to such differences as race, class and ethnicity. Women experience has been replaced by pluralism (Pessina and Mahler, 2003: 15). Feminists, with the realization of these triple stages have criticized the definition of "asylum seekers" in the 1951 Convention (Anker, 2002: 5). They demonstrate that this definition describes male person and does not give specific responses women's experiences.

Oswin (2001: 349-350) states that feminists draw attention in the asylum field and women's size and they have various criticisms that led some regulations adopt. In the beginning of those criticisms, violence against women comes first in the claim to have been asylum for refugee women. Feminists argue the common use of rape during the conflict, as "weapon of war". In addition, feminists have pointed out that violence that led to the escape of the women from the country continues in peacetime. Thus feminists have drawn attention to the more specific structural dimensions that shape violence against women. Feminists have drawn attention to the understanding of the social and repressive structures that take place under male violence against women and all forms of violence against women and violence and persecution they live only because of gender. In addition, feminists have provided the definition of oppressive, cultural and ideological rules and practices that led the continuation of secondary position of women as the violation of human rights in the claim of asylum.

Gender analysis represents a transformation not only for making women "visible" but also for conceptualization of migration concept. It has been drawn attention to the importance of comprehensive developments in feminist practice and theory by Kofman, Phizackle to, Raghuram and Sales (2000: 144) when searching the significance of women migration. Feminist theory, by taking into account all the inequalities, suggest a careful glance to experiences of the refuge and asylum-seekers (and men) in the light of gender, class, race, sexuality, such as multiple definitions. Thus, different woman situations in migration are tried to present.

With regard to immigration, the frame brought about by feminist theory seems to be appropriate in the size of refugee women. First, while feminist theory underlines the effect of gender differences in migration, it also allows seeing the social context in the background. In addition, it also underlines the need to draw attention to hear women's voices, to involve their perspective and in doing so need to take into account the diversity of women. Feminist theory indicates that the pressure for women is not the one, determined situation where the women are entirely helpless, instead it is a complex 
process, and women are rarely completely powerless against this pressure and women have versatile sources. This dimensions that feminist theory draws attention has led to the development of the evaluation of women with their power, not with their problems.

\subsection{Gender-Based Criticism in the Context of Asylum-Seekers Woman}

The concept of gender, as it is known, is a much more descriptive concept apart from biological sex that draws attention to the social roles of women and men. Only biologically explanation of female and male situation does not provide an adequate framework. On the contrary, the fact that manhood and womanhood are shaped by given certain roles imposed by society creates a state that should be considered in the explanation of all social events and the results. In this study on asylum and women size, looking from a gender-based critical perspective may have a great importance.

Gender is one of the oldest variables that shape human life and therefore should be taken into account in the migration process. However, the handling of the gender of the migration process is seen as a fairly new. In the last 25 years, very little effort in association of gender with international migration and migration theories that do not say something too much on gender are expressed by Grieco and Boyd (2000: 15) Gender analysis, on one hand, reveals women's suffering because of gender inequality and discrimination, on the other hand describes such situations that forms the bases of discrimination and differentiation as race, class, caste, ethnic background, age and disability (Byrne and Baden, 1995: 10). This discrimination and differentiation, particularly draws attention to the fundamental variables to be considered in the migration process.

With the discovery of the functionality of the concept of gender, it is possible to say that it is entered into the effort of its adoption to migration area. Since 1995, from executed practices as gender-related guideline to protect displaced people, many things about responsibilities in individual, corporate and national level have been learned. Gender-based violence is recognized as a fundamental principle in receiving the status of women asylum seekers. Convention on the gender-based violence and the Elimination of All Forms of Discrimination against Women. According to (CEDAW) the Committee, it is defined as direct violence based on individual's gender (sex) or social sex (gender). The causes of sexual and gender based violence are attitudes and practices that holds women in the inferior position in their relations with men in a society, (BMMYK, 2013: 21).

\subsection{The Effects of Migration on Refugee Women}

While the effects of the migration on women were being discussed, studies about asylum-seeker women were given priority. However, because the studies on this topic were not enough, it was benefitted from the general migration literature. In terms of migration and asylum, patriarchy creates an effect that increases the vulnerability of 
women in the migration process. Different forms that patriarchy takes shape are also effective in the migration process starting from the woman's decision to migrate. Davis and Winters (2001: 5-8) provide a rationale for much more adversely affected women than men from immigration related to greater risk of women on facing with an attack, encountering with the limitations of social rules a lot, having lack of access of relation network, having limited employment possibilities.

Affected areas of women asylum-seekers from migration are similar to the situations of all other migration categories. But about the asylum case, contagion is also possible in additional areas. These affected areas have been revealed in various studies. The effects of immigration and asylum can be examined in eight chapters.

\section{- Vulnerability of Women against Abuse-Exploitation and Violence}

Women's immigration today seems to be associated with the gain of women's more mobility but women are more turned on sexual exploitation and abuse than men. Sexual violence and especially mass rape had been used as a weapon of war against women in various historical periods. It is known that women are much more vulnerable to deprivation, various difficulties, and physical, sexual and verbal abuse.

\section{- $\quad$ Limited Access of Women to Services}

The limitations in the access to the various existing services in the community have been intended after immigration. Women, after the immigration, can reach the existing services less due to various obstacles that the society implements. Conditions such as various psycho-social pressures, different cultural expectations, women's lack of education increase marginalization rate of women in the host country. Thus, employment, social security and health programs are reached by women more limited.

\section{- $\quad$ Changes in Gender Roles with Migration}

According to the asylum case, migration is a process that is often unprepared. In addition to that, deterioration of family because of such conditions as the alone arrival of the woman, loss of her husband leads to a great transformation in their gender roles. In case of war, men members of the family joined the fighting groups or were seized. It would be a dramatic increase in the number of female heads of households; they could get new responsibilities about meeting children's and elderly relatives' needs. While women faced with an increasing workload, they have limited access to goods / services both for their children and for themselves. Women faced with doubled problem and responsibility and their roles vary (Canat, 1982: 13).

\section{- $\quad$ Limitation of Mobility Opportunities of Women's}

Women and girls are not treated on an equal footing with men; the mobility possibilities are more limited. Generally, it can be seen that women does not leave 
the house too much in the residential they go after the migration and it seems that they lose their mobility that is in their own country. During the escape, usually such documents as identity card, passport, and birth certificate are missing and there is no money for transportation. Besides, social rules and policies on women's freedom and mobility require the existence of a male companion to reach their exit permit (Newland, 2004: 5-6). It is possible to say that migration limit the movement of women with the combination of those factors.

\section{- Women's Psychological Impact}

New situations may arise in women's economic situation with migration. The status of women is often not changed or it can be worse. Women usually not working in their country do not work after immigration. Post-Traumatic Stress Disorder (PTSD) is expressed as a joint disorder between the women displaced more than a few months. Kreitz in phenomenological studies (2002) has seen indifference and discouragement among women. Sefa-Dedeh (1994) in his study of African women in refuge has revealed severe depression because of the pressure about everyday life faced by women.

\section{- Problems Connected with the Change of Women's Economic Status}

Women's economic situation may emerge new situations with migration. The status of women is often not changed, or can be worse. Women who don't have a job in their country are mostly not chosen to work with immigration. Workers are also in low-paid jobs under their training and security status most of the time.

\section{- Reconstruction of Identity}

Immigrants maintain old idealized images and identities of they have acquired in their own countries; it is said that new perception of idealized image and identity is not strong enough to replace completely with the old one. Buijs (1993: 10-11) emphasizes that a new home and a new identity occur during the migration process.

\section{- Differences Related to the Recognized as Refugees}

As indicated by the asylum experience of the feminist author as Ankur (2002:5) the experience of men is on the focus while women's experience seen as secondary. Lack of awareness about women's experience show itself in making structures for refugee status. "Women Resource Project" which was conducted in the UK has revealed that there is a lack of awareness about how gender shapes the cruelty experience for officials. (Reed, 2003: 114) Razack notes that their claim was accepted when women present themselves as the victims of patriarchal culture and states. Razack shows in his study that asylum applications accepted women present themselves as "Third world pleadings" or "Other foreign women". As it is seen, studies of the relevant subject focus on the different impact of immigration on women and men. These studies show that women harmonize their changes in home country and host country more easily, question traditional gender 
relations by gaining more autonomy with new employment patterns and balance the housewife, motherhood and work relations.

\section{- $\quad$ Feminist Social Work Practice and Feminization of Migration}

Feminist social services, according to Barker (1999: 173) was developed to help individuals and society to overcome the emotional and social problems caused by gender discrimination in social services and it is an integrity of values, skills and knowledge with a feminist orientation. Being a feminist social worker means have an impact on women's professional and personal relationships. (Dominelli, 2002b: 78). Feminism has led to an improvement in social services because feminism has demonstrated that economic conditions provide greater opportunities for women's freedom and strengthen. In feminist social services, gender is considered as the main reference point while working with women, and the race and class has been considered secondary. Addressing women's well-being as the primary in feminist social services prevent seeing women just as wives or mothers by social workers. (Featherstone, 2001: 3). Feminist social services were considered women experience around the world as the starting point of analysis and focused on the relationship between the position of women in society and personal status. It is a kind of social service that responds to the specific needs; creates equitable relationships in application-expert interaction and points to structural inequalities. (Dominelli, 2002b: 9). To meet the specific needs of women in an integrated manner and enable them to deal with complex side of life are a part of feminist social services. It focuses on the independent nature of social relations pointing to women's needs about interaction with other women, men and children. As well as proud place given to women in the analyses, feminist social workers challenge to gender-blind theory and practice that see women as under men. (Dominelli, 2002b: 9).

Anti-sexist theory and practice must be integrated in feminist social services. According to Thompson (2001: 61), the basic components of anti-sexist practice that are also shared by feminist social services include:

1) The purpose of social work intervention is empowerment, not adjustment. Social services do not help women to adapt "right place" in the family but help to gain strength for challenge against pressure they have experienced.

2) It is important to avoid stereotypic assumptions; for example, not to assume the man as the head of the family and primary decision-maker in two-parent families.

3) Family ideology reinforces sexism. Social work practice should be based on a balanced opinion on the family by identifying both the weakness and power of the family. It should include awareness-raising work not only about analysis of sexism but also for understanding that sexism is an obstacle to the solution of their problems and support problems. 
4) Women are "invisible" in a male-dominated society; their achievements and contributions are rarely accepted. Social workers should avoid this trap and make women's feelings, thoughts and work worthwhile. Micro-level social services increase the self-esteem of women; macro levels play a role in breaking the sexist devaluing women.

5) It includes challenging to the anti-sexist practice, sovereign discriminatory attitudes, values, application and judgments.

\section{Discussion}

The origin of feminist social work practice is the basic principles of feminism. It is an approach that considers woman's experience as a starting point, emphasizes on the concept of empowerment, aims to end patriarchy, helps to find the dynamics of the formation of problem that women have and finds the connection with the social structure, cares to build equitable relations. Challenge the existing power inequality is a very important tool. Because of these features, feminist social work is useful about liberating nature to deal with the cases brought by women's life experience in a complex and multifaceted process as migration.

Immigration and refugee women discussed in this study revealed what are different feminist situations in immigration. Recognizing the differences of women in the migration process has a great importance. In addition to gender, race and differences based on other reasons have a great importance to the configuration of feminist social services. On the other hand, migration process has the potential of preventing refugee women to realize their own power. Women can move away from realistic assessing of their power in the migration process because priority needs and problems come forward. Making women's power valuable is one of the main points in adaptation of feminist social services to immigration.

Immigration process has a potential to lead problems about making women's own decisions. Feminist social work is expected to be functional about realizing that people are active to make their own decisions. In addition, feminist social work is expected to be functional in awareness of refuge and asylum-seekers women about understanding the connection of their situation with the social reasons under immigration as an individual in the migration process.

It can be said that refuge and asylum-seekers women are affected more negatively from the asylum situation. Accordingly, women are more adversely affected than men in the size of pressures on asylum, making migration alone, increase in roles and responsibilities and difficulty in finding a job. However, a point to keep in mind here, it is the fact that each affected dynamics associated with other. In this context, it seems possible to say that these dimensions mutually affect each other. 


\section{References}

Akkaya, A. (2002). Mülteci kadınlar ve sığınmacı kadınlar. TophumveHukukDergisi, 2 (4) 75-83.

Anker, E. D. (2002). Refugee Law, Gender, and the Human Rights Paradigm. HarvardHumanRightsJournal

(15) http://www.law.harvard,edu/studoms/hri/

Bhugra, D. (2004). Migration and mental health. Acta Psychiatrica Scandinavia. 109: 243-258.

BMMYK. (2013). Sexual and gender-based violence against refugees, returnees and internally displaced persons. UNHCR Publications.

Boswell, C. (2002). Addressing the causes of migratory and refugee movements: The role of European Union. New Issues In Refugee Research Working Paper. UNHCR Evaluation and Policy Analysis Unit, no: 73.

Boyle, P. ve K. Halfacree. (1999). Migration and gender in the developed world. Routledge Research in Population and Migration.

Buijs, G. (1993). Introduction. migrantwomen: Crossing Boundaries and changing identities. Ed: Gina Buijs, Berg Publishing: 1-20.

Byrne, B. ve Baden, S. (1995). Gender, emergencies and humanitarian assistance. European Commission.

Canat, S. (1982). Ankara'nın abidinpaşa semtinde eşleri yurtdışında çalışan kadınların psikososyal sorunlarına ilişkin karşılaştırmalı bir araştırma. Ankara Üniversitesi Tıp Fakültesi Psikiyatri Kliniği Doçentlik Tezi.

Chant, S. ve S. A. Radcliffe. (1992). Migration and development: the importance of gender. Gender and Migration in Developing Countries. (S. Chant Ed. ) Belhaven Press, 1-30.

Crawley, H. (2000). Gender Persecution and the concept of politics in the asylum determination process. Forced Migration Review Gender and Displacement Issue, 9.

Davis, B. ve P. Winters. (2001). Gender, networks and Mexico-US migration. The Journal of Development Studies. 38 (2): 1-27.

Dominelli, L. (2002b). Feministsocial work theory and practice. Palgrave Publications.

Eastmond, M. (1993). Reconstructing life: Chilean refugee women and the dilemmas of exile. Migrant Women: Crossing Boundaries and Changing Identities (Gina Buijs, ED.) Berg Publishing, 35-54.

Featherstone, B. (2001). Where to for feminist social work?. Critical Social Work, 2 (1)

Friedman, R. A. (1992). Rape and domestic violence. Refugee Women on Their Mental Health Shattered Societies, Shattered Lives. (Cole, E., M. O. Espin ve E. D. Rothblum, Eds.) Harrington Park Press.

Grieco, M. E. ve M. Boyd. (2000). Women And Migration: Incorporating Gender into International Migration Theory. Center for Study of Population.

INSTRAW. (1994). .The migration of women: Methodological issues in the measurement and analysis of internal and internationalmigration, dominican republic. INSTRAW.

Içduygu, A. ve T. Ünalan. (1998). Türkiye'de içgöç: Sorunsal alanları ve araştırma yöntemleri. Türkiye'de İçgöç, Sorunsal Alanları ve Araştrrma Yöntemleri Konferansl: 6-8 haziran 1997, Türkiye Ekonomik ve Toplumsal Tarih Vakfı Yayınları.

Kadın Mülteci. (1997). Umuda Doğru Siğı̆nmacı ve Göşmenlerle Dayanışma Demeği Dergisi. 1 (2).

Künçek, ö. (1998). Kadın Mülteci. Umuda Doğru Slğınmact ve Gösmenlerle Dayanışma Demeği Dergisi, 2(6). 
Kofman, E. Phizacklea, A. Raghuram, P. ve R. Sales. (2000). Gender and International Migration in Europe Employment, Welfare And Politics. Routledge Press.

Martin F. S. (1992). Refugee Women. Zed Books Ltd.

Newland, K. (2004). Seeking protection: women in asylum and refugee resettlement processes. united nations division for advancements for women (DAW) consultative meeting on "Migration and Mobility and How This Movement Affect Women" Malmö. 2-4 December 2003.

Nikoliç-Ristanoviç, V. (2003). Refugee women in Serbia-Invisible victims of war in the former. Feminist Review. 73 (1) 2-6. www.proquest.umi.com

Oswin, N. (2001). An exploration of feminist approaches to refugee law. International Feminist Journal of Politics, 3 (3): 347-364.

Pavlish, C. (2005). Action responses of congolese refugee women. Journal of Nursing Scholarship. 37 (1): $10-17$.

Pessar, R. P. ve S. J. Mahler. (2003). Transnational migration: bringing gender in. TheInternationalMigration Review. 37 (I)

Reed, K. (2003). Endering asylum: The importance of diversity and context. FeministReview. 73 (1) www. proquest.umi.com

Thompson, N. (2001). Anti-discriminatorypractice. Third Edition. BASWPracticalSocial WorkSeries(Jo Campling, Ed.) Palgrave Publications.

Tomanbay, I. (1999). Sasyal Çallşma Sözlügü. Selvi Yayınevi. 